\title{
The MAP kinase Fus3 associates with and phosphorylates the upstream signaling component Ste5
}

\author{
Janice E. Kranz, ${ }^{1-3}$ Brett Satterberg, ${ }^{1}$ and Elaine A. Elion ${ }^{1,4}$ \\ ${ }^{1}$ Department of Biological Chemistry and Molecular Pharmacology, Harvard Medical School, \\ Boston, Massachusetts 02115 USA; ${ }^{2}$ Department of Cellular and Developmental Biology, Harvard University, Cambridge \\ Massachusetts, 02138 USA
}

\begin{abstract}
Activation of the Saccharomyces cerevisiae MAP kinase Fus3 is thought to occur via a linear pathway involving the sequential action of three proteins: Ste5, a protein of unknown function, Ste11, a MAPKK kinase homolog, and Ste7, a MAPK kinase homolog which phosphorylates and activates Fus3. In this report, we present evidence for a novel mechanism of Fus 3 activation that involves a direct association with Ste5, a protein not predicted to interact with Fus3. First, overexpression of Ste 5 suppresses fus 3 point mutations in an allele-specific manner and increases Fus 3 kinase activity in vitro. Second, Ste 5 associates with Fus 3 in vivo as demonstrated by the two-hybrid system and by two methods of copurification. Third, Ste 5 and Fus 3 associate prior to pheromone stimulation even when Fus3 is inactive, and in strains lacking Ste7 and Ste11. Fourth, Ste 5 is phosphorylated by Fus 3 in purified complexes and copurifies with an additional protein kinase(s). These observations suggest the possibility that Ste5 promotes signal transduction by tethering Fus 3 to its activating protein kinase(s).
\end{abstract}

[Key Words: Saccharomyces cerevisiae; MAP kinase; signal transduction; Fus3; Ste5]

Received November 16, 1993; accepted in revised form December 21, 1993.

Haploid Saccharomyces cerevisiae cells exposed to mating pheromone undergo cell-cycle arrest at $\mathrm{G}_{1} / \mathrm{Start}$, transcriptional activation of mating-specific genes, and cell elongation prior to mating (for review, see Sprague and Thorner 1994). Genetic analysis has identified numerous signal transduction components which regulate these responses (Mackay and Manney 1974; Hartwell 1980; for review, see Kurjan 1992; Sprague and Thorner 1994). Based on genetic data, these signal transduction components have been ordered into a linear pathway upstream of the transcription factor, Ste12, that is activated and phosphorylated in response to pheromone (Dolan et al. 1989; Dolan and Fields 1990). In this linear pathway model, signal transduction initiates by pheromone binding to a cell surface receptor, activating a heterotrimeric G-protein, then continues successively through the putative protein kinase Ste20, the Ste5 protein, the protein kinases Ste11 and Ste7, and culminating in the activation of Fus3 and Kss1, related protein kinases that activate Ste12 (Blinder et al. 1989; Elion et al. 1990, 1991b; Whiteway et al. 1990; Cairns et al. 1992; Gartner et al.

\footnotetext{
${ }^{3}$ Present address: Cubist Pharmaceuticals, 24 Emily Street, Cambridge, MA 02139 USA.

${ }^{4}$ Corresponding author.
}

1992; Leberer et al. 1992; Stevenson et al. 1992; Errede et al. 1993; Ramer and Davis 1993). Although this linear pathway is favored for its simplicity, interdependent or branched models have not been excluded (Elion et al. 1990; Stevenson et al. 1992; Elion et al. 1993).

The protein kinases Fus3, Kss1, Ste7, and Stell comprise a highly conserved regulatory module found in mammals as well as yeast (Errede and Levin 1993; Kosako et al. 1993; Lange-Carter et al. 1993; Neiman et al. 1993). Fus 3 and Kss 1 are homologues of MAP kinases (mitogen-activated protein kinases, MAPKs) or ERKs (extracellular signal-responsive kinases) that are activated by phosphorylation of tyrosine and threonine residues (Ray and Sturgill 1987; Boulton et al. 1991; for review, see Cobb et al. 1991; Pelech and Sanghera 1992a,1992b; Posada and Cooper 1992). Fus3 is also phosphorylated on these residues in response to $\alpha$-factor, and requires this modification for function (Gartner et al. 1992; Elion et al. 1993). Ste7 is related to the dual-specificity MAP kinase kinases (MAPKKs or MEKs, for MAP kinase/ERK kinase) (Crews and Erikson 1992; Seger et al. 1992; Kosako et al. 1993) that activate the MAP kinases (L'Allemain et al. 1992; Rossomando et al. 1992). Consistent with this, Ste 7 immune complexes phosphorylate Fus3 in vitro (Errede et al. 1993; Zhou et al. 1993). Stell is 
related to the MAPK kinase regulator, MAPKKK or MEKK (Lange-Carter et al. 1993), although it has yet to be shown that Stell directly activates Ste7. Ste20 is a putative protein kinase which to date lacks a mammalian counterpart and physiological target (Leberer et al. 1992, Ramer and Davis 1993|.

Ste 5 is the only signal transduction component that lacks obvious homology to a protein of known function (Leberer et al. 1993; Mukai et al. 1993; Perlman et al. 1993|, making its role difficult to assess. The STE5 gene encodes a 917-residue open reading frame with limited homology to two types of proteins, fueling speculation about its function (Leberer et al. 1993; Mukai et al. 1993; Perlman et al. 1993|. A 150-residue amino-terminal domain of Ste 5 is related to Farl, suggesting that Ste5 and Farl share a function in $G_{1}$ arrest (Leberer et al. 1993; Mukai et al. 1993; Perlman et al. 1993). This region overlaps a potential cysteine/histidine metal-binding motif, which together with a carboxy-terminal acidic domain, suggest that Ste 5 is a transcription factor (Leberer et al. 1993; Mukai et al. 1993; Perlman et al. 1993; Sprague and Thorner 1994). Neither possibility is consistent with the current placement of Ste5 in the signalling cascade. Thus, while genetic experiments demonstrate that Ste5 is essential for signal transduction (MacKay and Manney 1974; Hartwell 1980), the function of Ste5 remains a mystery.

Ste5 is thought to act at a single step between the Ste20 and Stell protein kinases on the basis of genetic analysis with hyperactive forms of Ste5 and Stell (Cairns et al. 1992; Leberer et al. 1992; Stevenson et al. 1992; Hasson et al. 1994); however, several observations suggest a more complex picture. First, hyperactive forms of Stel1 do not fully suppress ste5 mutations (Stevenson et al. 1992) and hyperactive forms of Ste5 only partially suppress G-protein mutants (Hasson et al. 1993). Second, overexpression of Ste5 suppresses ste4 (i.e., G-protein; MacKay 1983), fus3 (Elion et al. 1991a), and ste20 (Leberer et al. 1993/ mutations that block at different points in the signal transduction pathway. This ubiquitous pattern of suppression suggests that Ste 5 function cannot be defined in simple linear terms. Therefore, more complicated models for the role of Ste5 in signal transduction, such as an interdependence with other signal transduction components (e.g., the G-protein, Stel1, or Fus3), cannot be excluded (Elion et al. 1991a; Stevenson et al. 1992; Hasson, Blinder, Thorner, Jenness, 1994).

We present here a connection between Ste5 and Fus3, proteins not previously thought to interact directly on the basis of classical genetic experiments. Overexpression of Ste5 suppresses multiple defects of fus 3 point mutants in an allele-specific fashion, and also increases Fus3 kinase activity in vitro, suggesting a direct interaction between the two proteins. Consistent with these results, Ste 5 associates with Fus 3 in vivo, independently of both pheromone-stimulation and Fus 3 catalytic activity. Furthermore, Ste 5 is phosphorylated by Fus 3 and additional associated kinases in vitro. Taken together, these data suggest Ste5 associates in a complex with Fus3 and other protein kinase(s).

\section{Results}

Excess Ste5 suppresses $G_{1}$ arrest and transcription defects of fus3 mutants

We isolated the STE5 gene in two screens for suppressors of fus 3 mutations. In the first screen, STE 5 was identified as a suppressor of the mating defect of the fus $3-3$ mutant (Elion et al. 1991a). Subsequent analysis showed that STE5 overexpression increases mating and FUS1 transcription 1.5- to 2-fold, and partially suppresses the $G_{1}$ arrest defect of a fus3 null mutant (Elion et al. 1991a). In contrast, excess STE5 does not bypass a fus 3 kss 1 double mutant, suggesting STE5 either functions before Fus3 and Kss1, or requires either kinase for function (Elion et al. 1991a|. STE5 was also isolated as a suppressor of the $\alpha$-factor resistance of the fus $3-2$ mutant in a second screen that identified other efficient suppressors including FAR1 and STE12 (Elion et al. 1993; B. Satterberg and E.A. Elion, details to be published elsewhere). Subsequent analysis showed that overexpression of other upstream components le.g., STE2, STE4, STE7, STE11, STE20) did not suppress the fus3-2 mutant as efficiently as STE5 (data not shown). Thus, STE5 is a conspicuously strong suppressor of fus 3 mutations.

\section{Ste5 activates Fus3 kinase activity in vitro}

We determined the effect of Ste 5 overexpression on Fus3 kinase activity using an immune complex kinase assay that employs a hemagglutinin (HA) epitope-tagged Fus3, Fus3-HA (Elion et al. 1993). A typical assay reveals a profile of five or more associated proteins that are phosphorylated when Fus 3 is activated by pheromone (Fig. 1A, lane 2). Fus 3 kinase activity increases approximately fivefold when Ste5 is overexpressed, as shown by a fiveto sixfold increase in intensity of all phosphoproteins in the profile and the presence of at least three new associated substrates (apparent molecular mass of $\sim 115 \mathrm{kD}$, $\sim 95 \mathrm{kD}$, and $\sim 55 \mathrm{kD}$; Fig. 1A, lanes 4,6 ). Ste5 overexpression also increases Fus 3 kinase activity two- to threefold in the absence of pheromone induction (Fig. $1 \mathrm{~A}$, lanes 3,5 ). In contrast, a ste5 deletion mutation blocks Fus3 kinase activity, as expected (data not shown).

Ste 5 overproduction could cause an apparent increase in Fus 3 kinase activity by several mechanisms. First, the kinase activity could be due to Ste5; however, no kinase activity is seen in immune, complexes prepared from strains with Fus3 lacking the HA epitope (Fig. 1A, lanes 7,8 , nor in strains containing Fus3R42-HA, an inactive form of Fus3-HA (Elion et al. 1993; data not shown). Second, the effect could be an indirect consequence of an increase in the level of Fus3 due to enhanced activity of Ste12, which normally induces FUS3 mRNA $\sim 3$-fold (Elion et al. 1991b). However, equivalent amounts of Fus3 are immunoprecipitated in the absence and presence of excess Ste 5 (Figure 1B, cf. lanes 1 and 2 with 3-6). Third, Ste5 overproduction could simply increase the levels of the substrates that coprecipitate with Fus3. If this were the case, then Ste5 levels should not affect the 
A

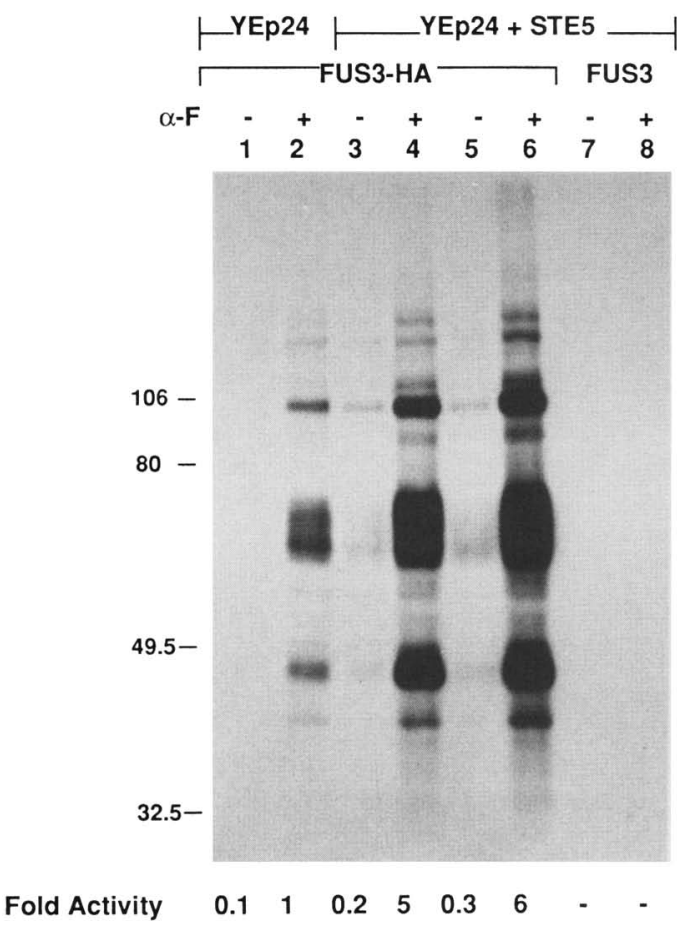

B

FUS3 protein

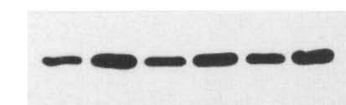

C

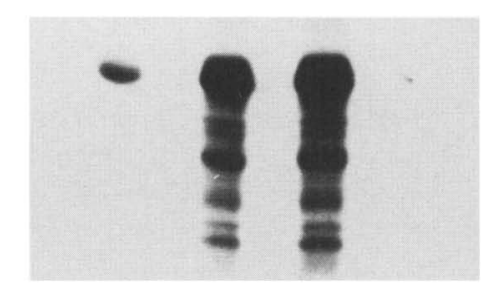

Figure 1. Effect of overexpression of STE5 on Fus3 kinase activity. (A) Kinase assays on Fus3-HA immune complexes. Kinase reactions were performed as described in Materials and methods. Reactions were stopped by the addition of loading buffer and separated on an $8 \%$ (30:0.8 acrylamide/bis-acrylamide)-SDS gel. Shown is a $1 \mathrm{hr}$ exposure of the autoradiograph. Numbers (left) mark positions of protein standards (in kilodaltons). Cells were induced for $1 \mathrm{hr}$ with $\alpha$-factor where indicated $(+)$. Lanes 1 and $2($ JY147) $=$ FUS3-HA (pYEE 1102$)+2 \mu$ vector (YEp24); lanes 3,4 and 5,6 (duplicate JY108 transformants) = FUS3-HA (pYEE1102) + STE5 $2 \mu$ (pJB223); lanes 7,8 $(J Y 106)=$ FUS3 (pYEE1100) + STE5 $2 \mu$ (pJB223). (B) Immunoblot of Fus3-HA immune complexes. Fus3-HA was detected with 12CA5 monoclonal antibody (Materials and methods). Samples are as in $A .|C|$ Phosphorylation of casein by Fus3-HA immune complexes. Kinase reactions were performed in the presence of $1 \mu \mathrm{g}$ casein, as described (Elion et al. 1993). Samples were separated on a $10 \%$ (38:2 acrylamide: bis-acrylamide)-SDS gel. Radioactivity in $A$ and $C$ were quantitated using a PhosphorImager (Molecular Dynamics). Shown are relative values. ability of Fus3 to phosphorylate an exogenous substrate. However, Fus 3 also phosphorylates casein, a specific substrate of Fus3 (Elion et al. 1993), fivefold more efficiently in the presence of excess Ste5 (Fig. 1C). Thus, Ste 5 is a limiting component for activation of Fus3.

\section{Allele-specific suppression of fus 3 point mutations by STE5}

The simplest explanation for both the suppression of fus 3 mutations and the increased Fus 3 kinase activity is that Ste 5 causes an increase in signal transduction which indirectly enhances activation of Fus3. To test this hypothesis, we compared the suppression of four fus 3 point mutations (Materials and methods; B. Satterberg and E.A. Elion, in prep.) by STE5 and a dominant hyperactive allele of STE11, STE11-4 (Stevenson et al. 1992). The fus3 mutations were introduced into a kss $1 \Delta$ strain to ensure that suppression be independent of Kssl, since it is redundant with Fus3 for signal transduction (Elion et al. 1991b). STE11-4 efficiently restores $\alpha$-factor sensitivity to fus3-2, fus3-211, and fus3-212, but has little effect on the most defective fus3 mutant, fus3-205 (Fig. 2). In contrast, STE5 overproduction suppresses both fus $3-2$ and fus3-205, but has little effect on fus3-211 and fus3-212. The preferential suppression of the most severely defective mutant, fus3-205, by STE5 is also reflected in the relative levels of restored FUS1 expression in these mutants (Fig. 2, legend). Thus, the contrasting pattern of suppression of fus 3 mutants by STE5 and STE11-4 suggests the effect of excess Ste 5 may not be due solely to a general increase in signal transduction. Indeed, while the suppression of fus 3 mutants by Ste 5 is not allele-specific in the classical sense of one mutation compensating for a second (Jarvik and Botstein 1975), it is allele-specific with respect to the ability of overexpressed Ste 5 to suppress different fus 3 point mutations, and may be a consequence of physical interactions between the two proteins.

\section{Ste 5 and Fus 3 interact in a two-hybrid system}

The allele-specific pattern of STE5 suppression suggested that Ste 5 and Fus3 physically interact, perhaps as kinase/regulator or kinase/substrate. We therefore tested whether Fus 3 and Ste5 interact in vivo, using a lexAbased (Zervos et al. 1993) two-hybrid system (Fields and Song 1989|. Fus3 was fused to a lexA DNA-binding domain that binds a lexA operator within the promoter of a reporter $\beta$-galactosidase gene (p)K103, Kamens et al. 1990|. Ste5 was fused to an acidic transcriptional activation domain that does not bind DNA /"B42," Ma and Ptashne 1987). Neither fusion protein alone induces $>5-$ 15 units of $\beta$-galactosidase expression (Table 1, Experiment I). In contrast, co-expression of both fusion proteins leads to a 100 -fold increase in $\beta$-galactosidase activity (Table 1). Expression of $\beta$-galactosidase requires both Ste 5 and Fus3, since other lexA and B42 fusion combinations do not induce $\beta$-galactosidase (e.g., lexA- 


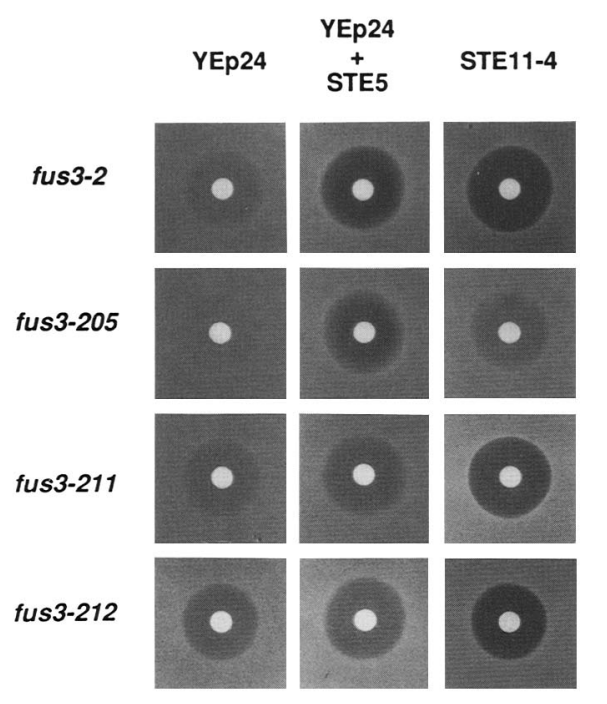

Figure 2. Effect of overexpressed STE5 and hyperactive STE11- 4 on $\alpha$-factor sensitivity of fus 3 mutants. Lawns of MATa

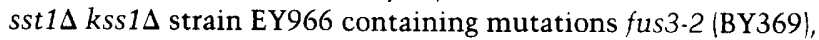
fus3-205 (BY360), or fus3-211 (BY366) and bearing either YEp24

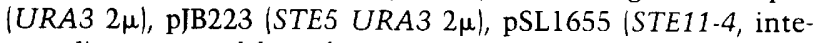
grated) were tested for $\alpha$-factor sensitivity by a halo assay using $5 \mu \mathrm{l}$ of $0.1 \mathrm{~mm} \alpha$-factor in dimethylsulfoxide. Strains were grown in SC medium lacking uracil to select for all plasmids, including the integrated STE11-4. Plates were photographed after $24 \mathrm{hr}$ at $30^{\circ} \mathrm{C}$. We measured FUS1 expression in a subset of these strains after a $1 \mathrm{hr}$ exposure to $\alpha$-factor with a Fusl- $\beta$ galactosidase reporter gene (pJB207). In the absence of excess Ste5, the fus3-2, fus3-205, and fus3-211 strains produce equivalent low levels of $\beta$-galactosidase activity $(1.5 \pm 0.1$ units $)$. Excess Ste5 has little effect on FUS1 expression in the fus3-211 strain (1.7 \pm 0.1 units), a threefold effect in the fus $3-2$ strain $(4.8 \pm 0.1$ units $)$ and a fourfold effect in the fus3-205 strain (6.0 \pm 0.2 units). Numbers are averages of duplicate transformants assayed twice.

bicoid, B42-CDC28 in Table 1). Thus, by the two-hybrid system, Ste 5 and Fus3 proteins interact.

Ste5 and Fus3 interact in the absence of Ste7, Ste11, and Ste12

It is possible that the two-hybrid interaction we detect is not due to a simple association between Fus3 and Ste5. For example, overexpression of Ste5 could activate the endogenous signal transduction pathway and cause lexA-Fus3 to associate with another protein, such as the transcription factor Ste12, a Fus3 substrate (Elion et al. 1993). Alternatively, B42-Ste5 could associate with lexA-Fus3 via intermediary proteins such as Stell or Ste7, which function between Ste5 and Fus3. We therefore repeated the two-hybrid experiment in strains deleted for STE7, STE11, or STE12, using a lexA-dependent $L E U 2$ reporter gene, and assayed growth on plates lacking leucine. Fus3 and Ste5 still associate in the absence of Ste7, Ste11, or Stel2 as shown by equivalent growth of STE, ste $7 \Delta$, ste $11 \Delta$, and ste $12 \Delta$ strains on media lacking leucine (data not shown). In addition, Fus3 and Ste 5 interact equivalently in an isogenic ste5 deletion strain (Table 1, Experiment II), indicating that endogenous Ste5 is not required for their association. The fact that Ste5 and Fus 3 still interact in the absence of these signal transduction proteins strongly suggests their association is direct.

\section{Ste5 and Fus3 copurify}

We investigated whether Ste5 and Fus3 copurify under conditions in which both proteins are functional, as predicted by the two-hybrid results. To detect Ste5, we constructed a fusion between glutathione-S-transferase and Ste5 (GST-Ste5) that is expressed from the GAL1 promoter and complements a ste $5 \Delta$ strain for mating (see Materials and methods). Fus3-HA immune complexes were prepared from strains containing either GST or GST-Ste5, then immunoblotted with anti-GST antiserum. As shown in Figure 3A, GST-Ste5, but not GST alone, coprecipitates with Fus3-HA, from both STE5 and ste $5 \Delta$ strains (cf. lanes 3, 4, 6 and 7 to lane 5). The presence of GST-Ste5 is not due to nonspecific binding to the antibody or protein-A-Sepharose as it is not recovered from strains lacking the epitope tag on Fus3 (lane 1). Thus, the ability to copurify GST-Ste5 with Fus3-HA is dependent on both Ste 5 and Fus3. Furthermore, Ste 5 and Fus 3 associate regardless of whether Fus 3 is active $\mid \alpha-$ factor-induced, lanes 4,7 ) or inactive (uninduced, lanes $3,6)$.

To confirm the specificity of the association between Ste5 and Fus3, we did the complementary experiment of purifying GST and GST-Ste5 with glutathione-agarose, and assaying for the presence of Fus3-HA. Identical results were seen: Fus3-HA copurifies with GST-Ste5 but

Table 1. $\beta$-Galactosidase activity induced by interaction of Fus3 and Ste5 fusion proteins in a two-hybrid system

\begin{tabular}{|c|c|c|c|c|c|}
\hline & \multirow{3}{*}{$\begin{array}{l}\text { Host } \\
\text { strain }\end{array}$} & \multirow{3}{*}{$\begin{array}{l}\text { lexA } \\
\text { fusion } \\
\text { plasmid }^{\text {a }}\end{array}$} & \multicolumn{3}{|c|}{$\begin{array}{l}\beta \text {-Galactosidase } \\
\text { activity (units) }\end{array}$} \\
\hline & & & \multicolumn{3}{|c|}{ B42 fusion plasmid ${ }^{2}$} \\
\hline & & & $\varnothing$ & $\mathrm{CDC} 28$ & STE5 \\
\hline \multirow[t]{3}{*}{ I } & STE5 & $\varnothing$ & 9 & 8 & 7 \\
\hline & & bicoid & 10 & 14 & 14 \\
\hline & & FUS3 & 13 & 13 & 1200 \\
\hline \multirow[t]{2}{*}{ II } & STE5 & FUS3 & 15 & N.D. & 310 \\
\hline & ste5s & FUS3 & 15 & N.D. & 360 \\
\hline
\end{tabular}

(N.D.) Not determined.

${ }^{a}$ Specific plasmids are listed in Table $4 . \varnothing$ refers to the vector alone. LexA vector is LexA202PL, bicoid fusion is pHM $\varnothing$, FUS3 is LexA-FUS3; B42 fusion vector is pJG4-5, CDC28 fusion is pYBS150; STE5 fusion is pYBS146.

${ }^{b}$ Values are Miller units of $\beta$-galactosidase activity /Craven 1965), averaged from two experiments in which two independent plasmid-bearing transformants were assayed. All assays were done in yeast strain EGY048 (STE5) or a ste $5 \Delta$ derivative carrying a LacZ reporter plasmid. 


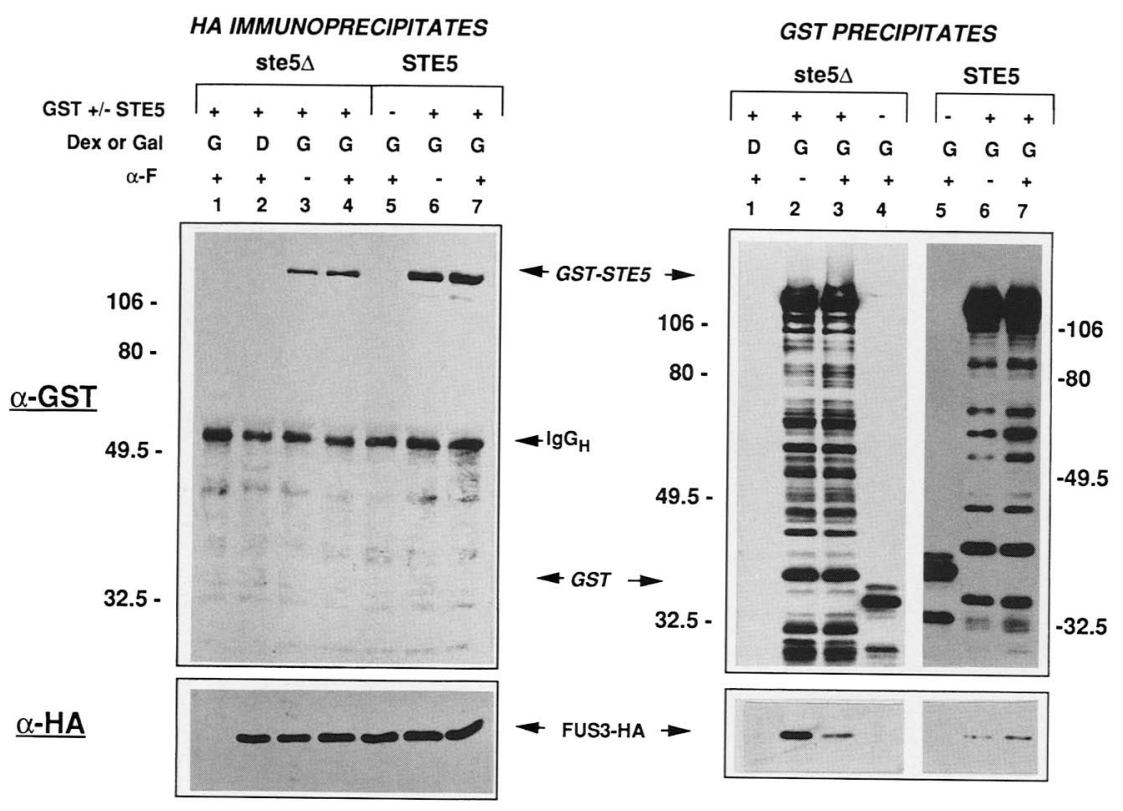

Figure 3. GST-Ste5 and Fus3-HA co-precipitate in vivo. Immunoblot analysis of GST-Ste5 in Fus3-HA immune complexes. (Left) Fus3-HA was immunoprecipitated with 12CA5 monoclonal antibody from ste $5 \Delta$ (lanes 1-4) or STE5 ${ }^{+}$(lanes 5-7) strains carrying FUS3-HA on pYEE 1102 (except lane 1, which has FUS3 on pYEE 1 100) and either GST (lane 5) or GSTSTE5 (lanes 1-4 and 6,7). Cells were pregrown in either galactose $(G)$ or dextrose (D), prior to being induced for $1 \mathrm{hr}$ with $\alpha$-factor, where indicated $(+)$. Duplicate samples were run on separate gels for immunoblot analysis with either antiserum against GST (top) or 12CA5 (bottom). Note that the secondary antibody (goat anti-rabbit IgG-HRP/ cross-reacts with the 12CA5 Ig in the immune complexes. Numbers (left) mark positions of protein standards (in kilodaltons). The expected position of GST protein is indicated. Strains are BY845 (lane 1), BY846 (lanes 2-4), BY 784 (lane 5), and BY786 (lanes 6,7) (right). Immunoblot analysis of Fus3-HA associated with GST-Ste5. GST or GST-Ste5 was purified with glutathione-agarose (see Materials and methods), and duplicate samples were run on separate gels and immunoblotted with either 12CA5 (top) or affinity-purified rabbit antiserum against GST (bottom). Numbers mark positions of protein standards (in kilodaltons). Results are shown from two separate experiments. Cells were grown in either galactose $(G)$ or dextrose (D), and were induced for $1 \mathrm{hr}$ with $\alpha$-factor before extract preparation,

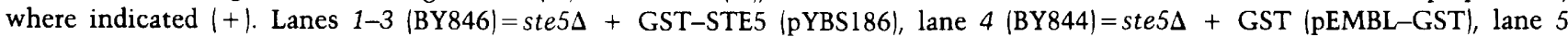
$(B Y 784)=S T E 5^{+}+$GST $(\mathrm{pEMBL}-\mathrm{GST})$, and lanes $6,7(\mathrm{BY} 786)=S T E 5^{+}+\mathrm{GST}-\mathrm{STE} 5(\mathrm{pYBS} 186)$.

not with GST (Fig. 3A, cf. lanes 2 and 3 with 4 ; lanes 6 and 7 with 5). Again, the association between Ste5 and Fus3 could be detected in extracts of both $\alpha$-factor-induced (lanes 3,7) and -uninduced (lanes 2,6) cells. Thus, Ste5 and Fus3 associate in vivo independently of pheromone induction.

\section{Ste5 associates with a catalytically inactive form of} Fus3

The association between Ste5 and Fus3 prior to pheromone stimulation (Fig. 3A) and in ste strains suggests that activation of Fus3 is not a prerequisite for association with Ste5. We tested this possibility by repeating both types of copurification with a catalytically impaired form of Fus3-HA, Fus3R42-HA. As shown in Figure 4, GST-Ste5 associates equivalently with both functional (Fus3-HA, lanes 3,4, left and right) and nonfunctional (Fus3R42-HA, lanes 6,7, left and right) forms of Fus3. Thus, Fus3 need not be catalytically active in order to associate with Ste5.

\section{Fus3 phosphorylates Ste5 in purified complexes}

We next determined whether Ste5 is phosphorylated by Fus3 as evidence of a direct association. Fus3 was first tested for its ability to phosphorylate Ste5 using the B42Ste5 protein (Table 1) as an exogenous substrate. Equivalent amounts of B42-Ste5 and Fus3-HA were immunoprecipitated (Fig. 5, right) and tested in the kinase assay
(Elion et al. 1993). B42-Ste5 is only slightly phosphorylated when assayed alone (Fig. 5, left, lane 5) or in the presence of inactive Fus3R42-HA (lane 6). In contrast, the addition of active Fus 3 causes a significant increase in the amount of B42-Ste5 phosphorylation (Fig. 5, left, lanes 2, 4). Equivalent results were seen when B42-Ste5 was prepared from either fus $3 \Delta$ or FUS3 strains (data not shown). Moreover, this phosphorylation is specific for Ste5, since B42 alone is not phosphorylated (lane 1 and data not shown).

The fact that Fus 3 could phosphorylate Ste 5 in vitro suggested that phosphorylation could be used to detect a direct association between the two proteins when they associate in vivo. We therefore performed kinase assays on Fus3-HA immunoprecipitated from strains containing GST-Ste5 (Fig. 6A, lanes 1-9). As seen previously for wild-type Ste5 (Fig. 1), overexpression of GST-Ste5 causes a large increase in Fus 3 kinase activity both in the absence and presence of $\alpha$-factor (Fig. 6A, cf. lanes 8 and 9 with 6 and 7), even under repressive conditions when GST-Ste5 is produced at very low levels (Fig. 6A, lanes 13,18 ). Significantly, overexpression of GST-Ste5 produces a prominent new phosphoprotein of $\sim 120 \mathrm{kD}$, the size observed for GST-Ste5 (Fig. 6A, lanes 8,9), and consistent with the expression of GST-Ste5 (Fig. 6A, cf. lanes 8 and 9 with lanes 6 and 7). Furthermore, the $\sim 120$ $\mathrm{kD}$ phosphoprotein is present in extracts from both untreated (lane 8) and pheromone-treated (lane 9) cells, consistent with the association of Ste5 and Fus3.

To prove that the $\sim 120-\mathrm{kD}$ substrate is GST-Ste 5 , we 
Figure 4. Association of GST-Ste5 with catalytically-inactive Fus3. Fus3R42-HA and GST-STE5 were purified exactly as described in Fig. 3 from STES ${ }^{* \wedge}$ strains carrying FusR42-HA (on pYBS351) and either GST (lane 1] or GST-STE5 (lanes 2-7). Duplicate 12CA5 immunoprecipitates (left) and glutathione-agarose precipitates (right) were run on separate gels for immunoblot analysis with either anti-GST antiserum [top) or anti-HA monoclonal antibody (bottom). Strains are $S T E 5^{\wedge}$ fus $3^{\wedge}$ (EY1095) containing Fus3-HA and GST (lane $\mathrm{i}=\mathrm{BY784}$ ), Fus3-HA and GST-Ste5 (lanes 2-4 = BY786), or fus3R42-HA and GSTSte5 (lanes 5-7 = JY165). Samples were $\mathrm{s}$ eparated on $10 \%$ (30:0.8 acrylamide/bisacrylaraide)-SDS gels.
HA IMMUNOPRECIPITATES

GST PRECIPITATES

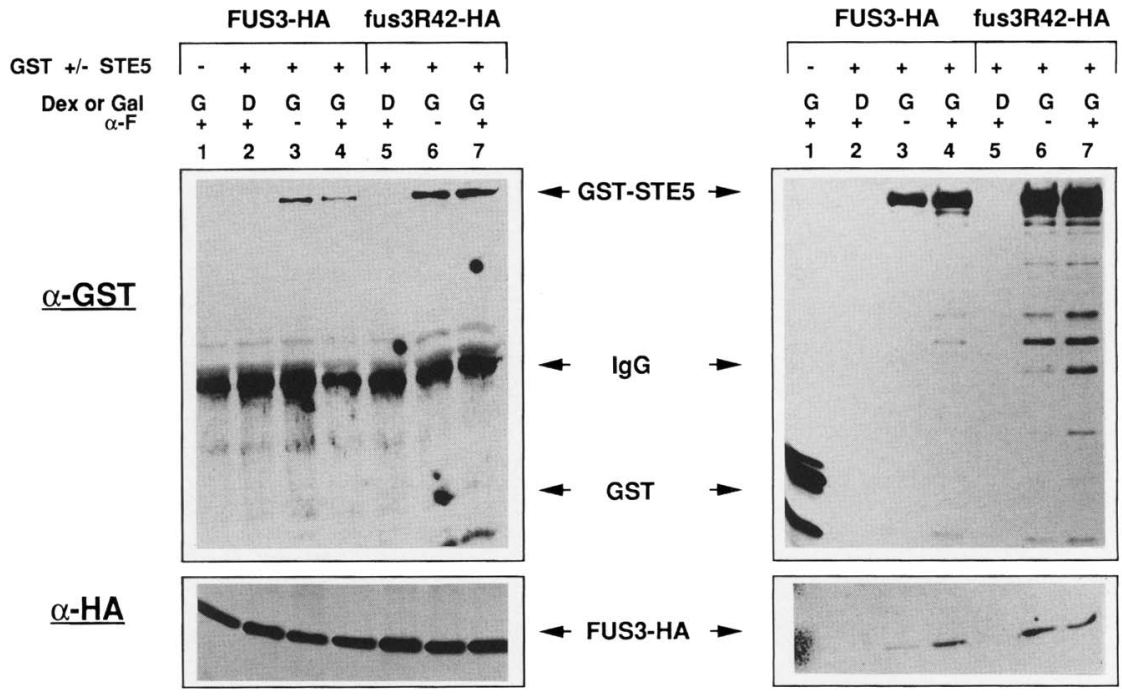

determined whether it could be purified with glutathione-agarose. Fus3-HA kinase reactions were solubilized and incubated with glutathione-agarose (see Materials and methods). Of the nine or more phosphoproteins, only the $120-\mathrm{kD}$ protein bound to glutathione-agarose (Fig. 6B, lane 2), demonstrating that it is GST-Ste5. Furthermore, treatment of the purified protein with thrombin, which recognizes a site engineered between GST

\section{A}

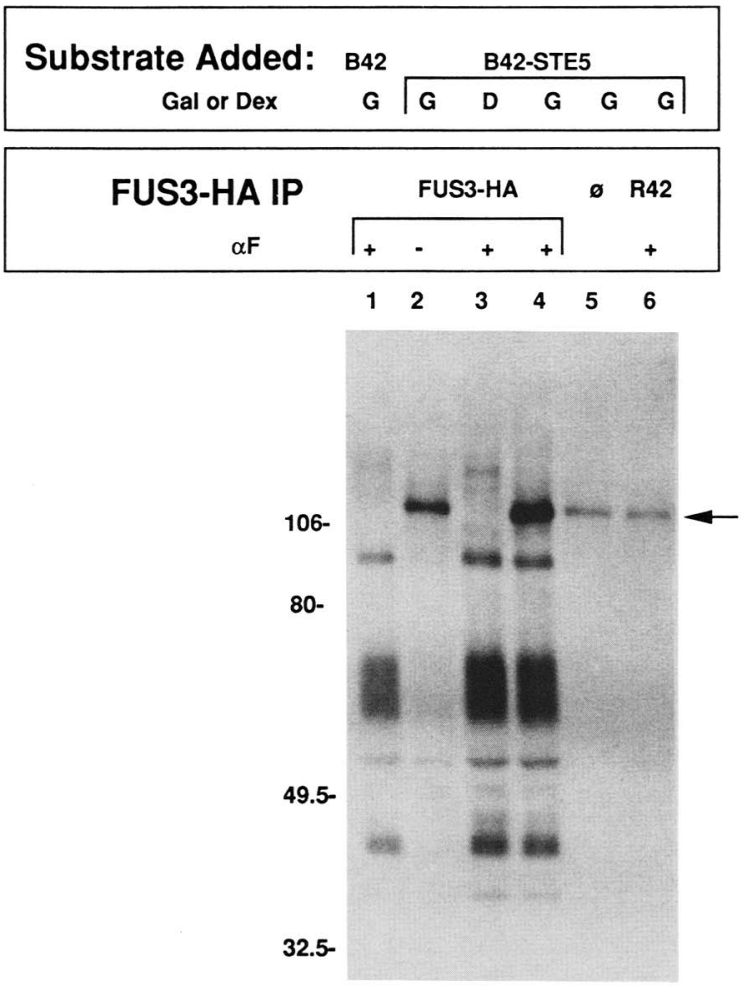

B

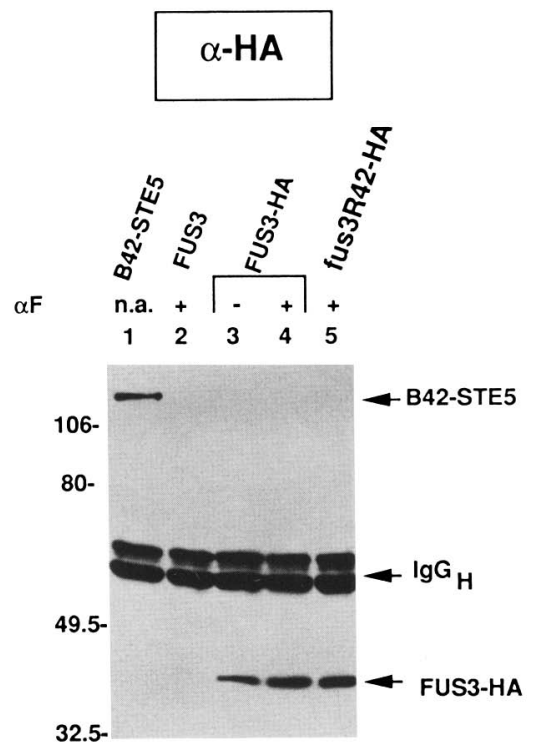

Figure 5. Phosphorylation of B42-Ste 5 by Fus3-HA immune complexes. Kinase assays (left) were performed on B42-Ste5 and B42 immunoprecipitates alone (lane 5) or in the presence of Fus3-HA immune complexes. Strains containing the galactose-inducible fusion proteins B42 (BY872) or B42-Ste5 (BY873) were grown in galactose (G) or dextrose (D), as indicated. Fusion proteins were immunoprecipitated with 12CA5 monoclonal antibody from $200 \mathrm{Mg}$ of yeast extract in RIPA buffer, then washed 5 times

before being added to Fus3-HA immune complexes. Fus3-HA immune complexes were prepared from Fus3-HA-containing strain EY960 (lanes 1-4) or fus3R42-HA (catalytically inactive)-containing strain EY1 144 (lane 6). Fus3-HA strains were treated for 1. hr with a-factor where indicated (+). Samples were separated on an 8\% (30:0.8 acrylamide/bis-acrylamide)-SDS gel. (Right) Immunoblot of Fus3-HA and B42-Ste5-HA immunoprecipitates. Duplicate immunoprecipitates from those used in the kinase assay were performed using 12CA5 monoclonal antibody. 

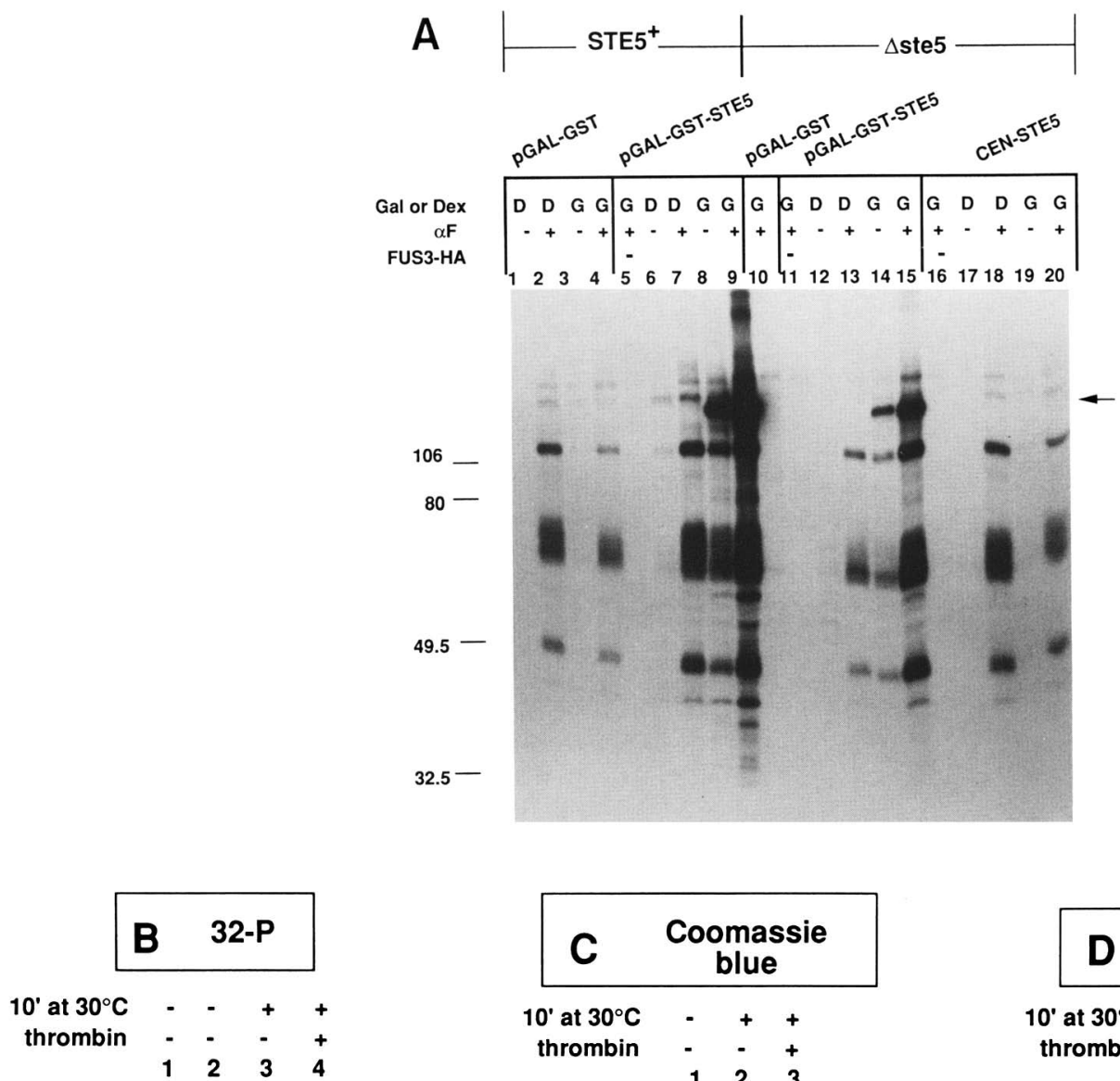
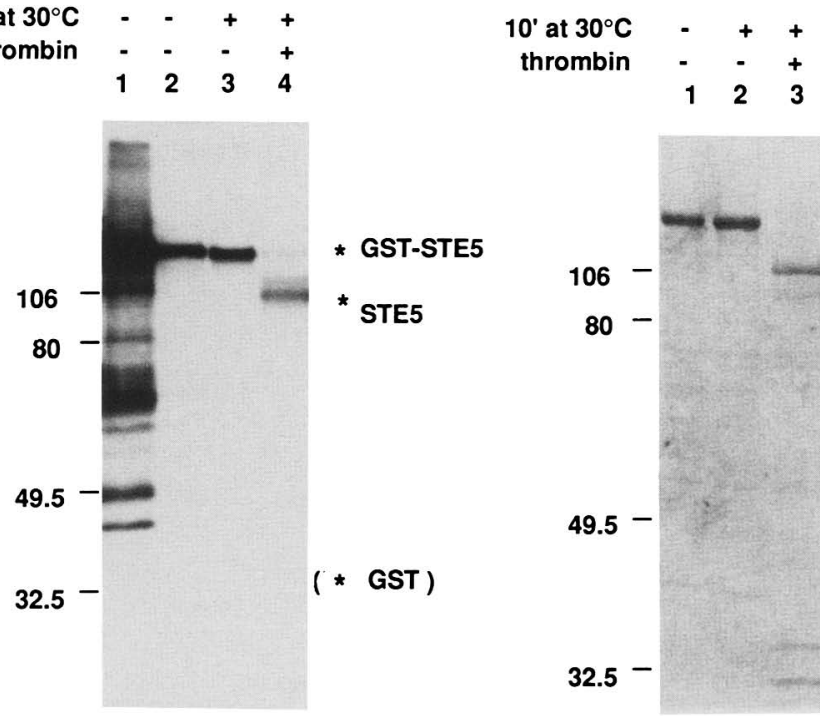

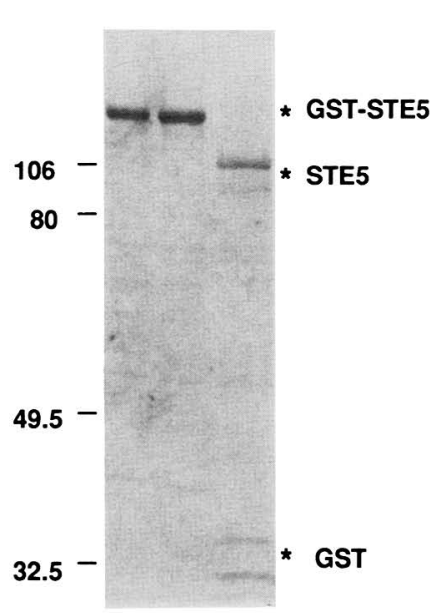

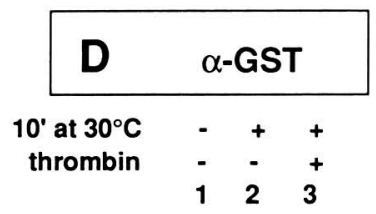

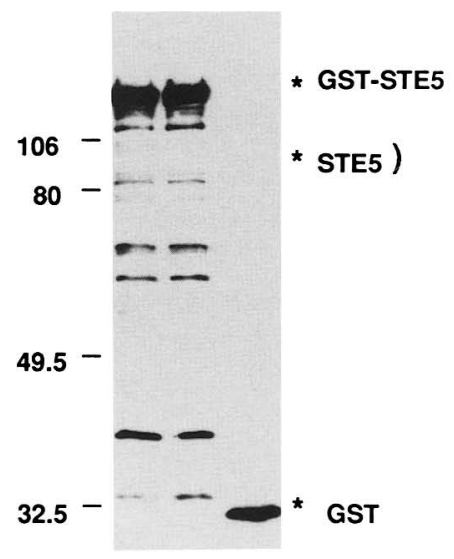

Figure 6. Effect of GST-Ste5 on Fus3-HA kinase assay. (A) Kinase assays of Fus3-HA immune complexes. Total protein (200 $\mu \mathrm{g}$ ) of each strain was immunoprecipitated with 12CA5 monoclonal antibody, and Fus3-HA kinase assays were performed as described in Materials and methods. All strains contained Fus3-HA (pYEE1102) except those in lanes 5, 11, and 16, which contained Fus3 lacking the HA epitope (pYEE1100) indicated by (-). Lanes $1-9$ are from a STE5 ${ }^{+}$strain (EY1095) containing GST (lanes $\left.1-4\right)$ or GST-Ste5 (lanes 5-9). Lanes 10-20 are from a ste5A strain (BY819) containing GST (lane 10), GST-Ste5 (lanes 11-15), or STE5 CEN (lanes 16-20). Cells were grown in either galactose $(G)$, to induce expression of the GST fusion proteins, or dextrose (D), to repress their expression, and were induced for $1 \mathrm{hr}$ with $\alpha$-factor, where indicated $(+1 .(B)$ Purification and thrombin digestion of GST-Ste5 from kinase assays of Fus3-HA immune complexes. A kinase reaction identical to lane 9 of $A$ was solubilized in RIPA buffer and incubated with glutathione-agarose. The GST precipitates were washed, analyzed directly (lane 2), incubated with thrombin (lane 4), or incubated without thrombin (lane 3). (C) Thrombin digestion of purified GST-Ste5. GST-Ste5 was purified with glutathione-agarose from 200 $\mu \mathrm{g}$ of whole cell extract from the $S T E 5^{+}$strain (BY786) containing Fus3-HA + GST-STE5. Thrombin was added (lane 3) or not added (lanes 1,2), and the precipitates were incubated at $30^{\circ} \mathrm{C}$ for 10 min (lanes 2,3). Samples were separated on a 10\% SDS-polyacrylamide gel and visualized with Coomassie blue. $(D)$ Immunoblot with $\alpha$-GST of duplicate samples from $C$. Note that a GST doublet is typically seen but the smaller species was inadvertently run off this gel. 
and Ste5, shows that the vast majority of the phosphorylation is on Ste5, not GST. Cleavage of the $\sim 120-\mathrm{kD}$ phosphoprotein with thrombin produces a single phosphoprotein of $\sim 100 \mathrm{kD}$ equivalent in size to the Ste 5 portion of GST-Ste5 (Fig. 6B, lane 4). In contrast, cleavage of purified GST-Ste 5 with thrombin produces three major polypeptides, one of $\sim 100 \mathrm{kD}$, and two of $\sim 30 \mathrm{kD}$ that are detected by GST antiserum (Fig. 6C, D). Thus, Fus3 phosphorylates Ste5 when the two proteins associate, proving they directly contact one another.

\section{Ste5 associates with an additional protein kinase(s)}

One explanation for the interaction between Ste5 and Fus3 is that Ste 5 mediates the association between Fus3 and its upstream activating kinases. To test this possibility, we examined whether Ste5 associates with additional protein kinases. We first determined whether GST-Ste5 is still phosphorylated in vitro when copurified with catalytically inactive Fus3R42-HA. Normally, no Fus3 kinase activity is detected in kinase assays of Fus3R42-HA (Fig. 7A, lane 4; Elion et al. 1993). Nevertheless, GST-Ste5 is still residually phosphorylated in immune complexes with Fus3R42 (Fig. 7A, lanes 5, 6). This phosphorylation could reflect residual Fus 3 kinase activity that is now detectable in the presence of excess GST-Ste5. Indeed, an equivalent ERK2 MAP kinase mutant retains $5 \%$ activity in vitro when assayed with myelin basic protein (Robbins et al. 1993). However, identical Fus3R42-HA/GST-Ste5 immune complexes do not phosphorylate a large excess of MBP (data not shown), a proven Fus3 substrate (Elion et al. 1993). Thus, GSTSte5 may be phosphorylated by another protein kinase(s) present in the complex whose activity is independent of Fus3 and specific for GST-Ste5. This possibility is strongly supported by the fact that GST-Ste5 purified from both FUS3 and fus $3 \Delta$ strains is associated with a protein kinase(s) which phosphorylates GST-Ste5 in the kinase assay (Fig. 7B; see Materials and methods). Significantly, only full-length GST-Ste5 is phosphorylated, although immunoblot analysis shows the presence of shorter degradation products (Figs. 3 and 4). Thus, an additional protein kinase(s) that specifically recognizes Ste 5 can copurify with both Fus3 and Ste5, suggesting the existence of a multimeric complex.

\section{Discussion}

\section{A novel linkage between Ste5 and Fus3}

We demonstrate five features of a previously unknown relationship between Ste5 and Fus3, proteins believed to be positioned three steps apart in the signal transduction pathway and not predicted to interact. First, overexpression of Ste 5 suppresses fus 3 point mutations in an allelespecific manner. Second, Ste5 is a limiting component for activation of Fus 3 kinase. Third, Ste 5 associates with Fus3 in vivo as demonstrated by the two-hybrid system and by two methods of copurification. Fourth, Ste5 and Fus3 associate prior to pheromone stimulation, when

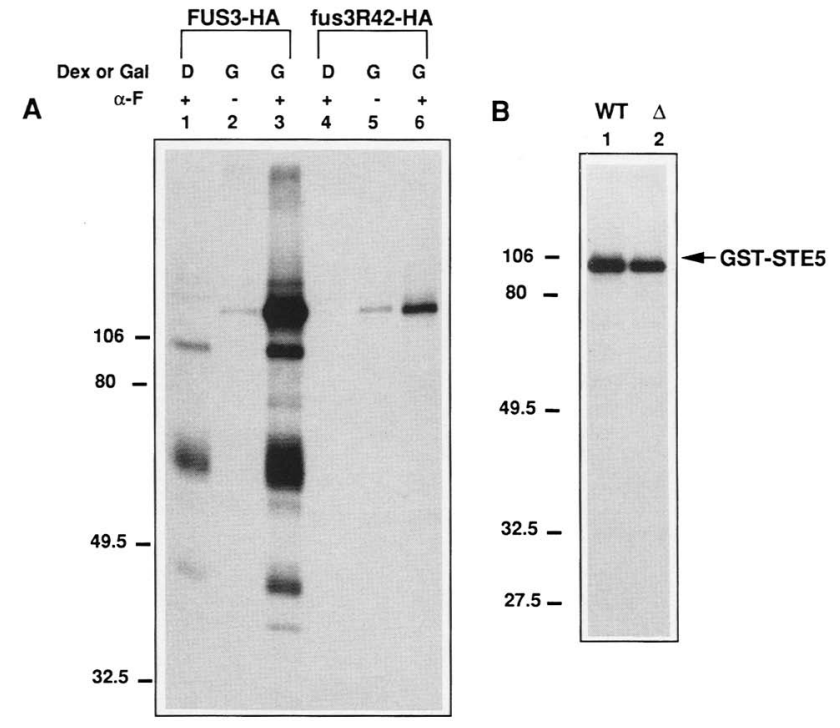

Figure 7. GST-Ste5 is associated with a Fus3-independent protein kinase(s). $(A)$ Kinase assays of active Fus3-HA (BY786, lanes 1-3) and inactive Fus3R42-HA (JY165, lanes 4-6) from strains harboring GST-Ste5 (pYBS186). Kinase assays were performed as described in Materials and methods. GST-Ste5 was expressed by growth in galactose $(G)$, repressed by growth in dextrose (D). Cells were induced for $1 \mathrm{hr}$ with $\alpha$-factor where indicated $(+) .(B)$ Phosphorylation of GST-Ste 5 by an associated protein kinase (s). Strains were grown in galactose to induce expression of GST-Ste5 and then induced for $1 \mathrm{hr}$ with $\alpha$-factor. GST-Ste5 was purified from FUS3 (lane 1, EY1462) and fus $3 \Delta$ (lane 2, EY1450) extracts with glutathione-agarose and incubated in a standard kinase assay for $8 \mathrm{~min}$ (Elion et al. 1993). Samples were separated on a $10 \%$ SDS-polyacrylamide gel.

Fus3 is inactive, and in the absence of Ste7 and Ste11. Fifth, Ste 5 is phosphorylated by Fus 3 and additional protein kinase(s) in purified complexes. These data strongly suggest that Ste 5 and Fus 3 directly interact. The simpler explanation for the effects of Ste5 on Fus3, that of overexpressing a limiting component upstream of Fus 3 in the signal transduction pathway, is highly unlikely. This purely indirect mechanism for the effects of Ste 5 on Fus3 does not explain the allele-specific suppression, the physical interaction, nor the fact that Ste 5 can be phosphorylated by Fus3.

\section{Evidence of a direct role for Ste5 in Fus3 activation: a model for Ste5 function}

Our results can best be explained by a model in which Ste 5 serves a structural role to tether Fus 3 to its activating protein kinases, Ste 7 and Stell (Fig. 8A). In this model, Ste 5 positively regulates Fus 3 kinase activity by virtue of its association with Fus3; Ste5 overproduction could cause a higher proportion of Fus 3 molecules to be associated in an activating complex. The allele-specific suppression of a loss-of-function fus 3 mutation by excess Ste5, coupled with the ability of Ste5 to enhance Fus3 kinase activity, and to associate with Fus3 and an additional protein kinase(s), are all consistent with this 

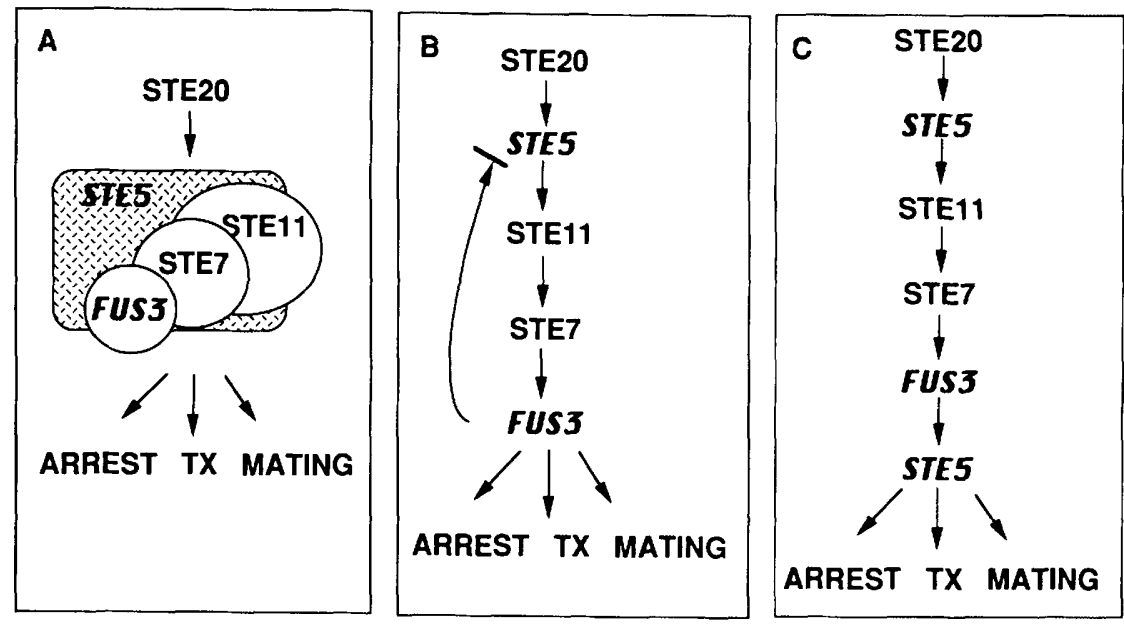

Figure 8. Three models to explain the interaction between Ste 5 and Fus3. The three models stem from the proposed linear pathway of signal transduction in the pheromone response pathway, established by genetic experiments using hyperactive forms of STE11 (Cairns et al. 1992; Gartner et al. 1992; Leberer et al. 1992; Stevenson et al. 1992; Zhou et al. 1993). See text for explanation. $(A)$ Ste5 directly regulates Fus 3 by serving as a nucleation site for Fus 3 and activating kinases, Ste7, and Stel 1 , facilitating rapid signal amplification. The phosphorylation reactions follow the established linear pathway (e.g., STE $11 \rightarrow$ STE $7 \rightarrow$ FUS3). Ste20 is positioned directly upstream of Ste5 as hypothesized by Leberer et al. (1992). This model neither precludes nor requires a catalytic role for Ste5. $(B)$ Feedback regulation between Fus3 and Ste5, which could be negative $(N)$ lor positive $(\rightarrow)$. (C) An additional role for Ste5p downstream of Fus3.

model. Moreover, the association of Ste 5 with Fus 3 in the absence of pheromone induction and catalytically active Fus 3 is consistent with a positive regulatory role for Ste5 that would be required prior to pheromone stimulation. Indeed, this interaction contrasts sharply with the interaction between Fus3 and Ste12, a proven Fus3 substrate that appears to associate preferentially with active Fus3 (Elion et al. 1993). Furthermore, a prediction of this model is that Ste5 should also interact with Stell and Ste7, and Fus3 should interact with Ste11. Both the two-hybrid analysis and copurification studies suggests that this is the case (B. Satterberg, D. Lyons, and E.A. Elion, in prep.).

Thus, the primary role for Ste 5 as a nucleation site for the assembly of protein kinases involved in signal transduction is consistent with the previous epistasis analyses (MacKay 1983; Blinder et al. 1989; Elion et al. 1991a, b; Cairns et al. 1992; Leberer et al. 1992, 1993; Stevenson et al. 1992; Hasson et al. 1994; Ramer and Davis 1993), if we assume that the enzymatic reactions, but not necessarily the physical associations, are in a linear series. The fact that Ste5 is so limiting for Fus3 activation may sug. gest Ste 5 is in low abundance, consistent with a critical role as a potent activator. Furthermore, the existence of a complex between Ste 5 and Fus 3 also permits feedback regulation between the two proteins, which would explain why Fus3 phosphorylates Ste5.

\section{Alternative interpretations of the Ste5/Fus3 interaction}

Alternative explanations for the interaction between Ste 5 and Fus 3 are based on the premise that Ste 5 interacts with Fus 3 only as a substrate. The first alternative is that Ste5 and Fus3 associate solely to feedback regulate Ste5, resulting in either down-regulation or activation of signal transduction (Fig. 8B). The feedback model does not readily explain the allele-specific suppression of fus3-205, nor the fact that the association between Fus3 and Ste5 is not enhanced by pheromone-induction as might be expected. However, numerous MAP kinases have been shown to phosphorylate upstream signal transduction components in vitro, including the EGF receptor (for review, see Pelech and Sanghera 1992a) and Raf-1 kinase (Lee et al. 1992). Moreover, Fus3 has been shown to phosphorylate Ste7 in vitro (Zhou et al. 1993), and genetic analysis suggests Fus3 negatively regulates its own activation (Gartner et al. 1992). Thus, it is plausible that Fus3 may feedback regulate Ste5, but perhaps in the context of a multimeric complex.

A second alternative is that Ste5 acts in a second place directly downstream of Fus 3 to promote $G_{1}$ arrest, transcription, and mating, requiring phosphorylation by Fus 3 for function (Fig. 8C). Both the interaction and phosphorylation data are consistent with Ste5 interacting with Fus3 as a substrate. This interpretation could explain the inability of hyperactive alleles of STE11 to fully suppress a ste5 $\Delta$ mutant (Stevenson et al. 1992), the ability of high copy STE5 to suppress a far 1 mutant (Leberer et al. 1993), and resemblance of Ste5 to transcription factors (Mukai et al. 1993; Perlman et al. 1993). However, many observations argue against this interpretation. First, overproduced Ste5 is an allele-specific suppressor of a mutant, fus3-205, that appears to be defective in activation (B. Satterberg and E.A. Elion, in prep.). Second, Ste5 associates with Fus3 prior to pheromone stimulation regardless of Fus 3 activity, as might be expected for a regulatory interaction. Third, a far 1 mutation can be suppressed by increasing the activity of other upstream components besides Ste5 (E.A. Elion, unpubl.). Fourth, Ste5 does not appear to play a direct role in transcription activation, because a ste $5 \Delta$ ste $12 \Delta$ double mutant ap- 
pears no more defective in transcription than a ste12A single mutant (E.A. Elion, unpubl.).

\section{Precedents for protein complexes mediating signal transduction}

The notion of a signal transduction pathway operating through a multimeric protein complex, with at least one protein playing a primarily structural role, is not unprecedented. One example comes from bacterial chemotaxis. Though originally ordered by double mutant studies in a linear pathway [receptors $\rightarrow \mathrm{CheW}$ (a protein of unknown function) $\rightarrow$ CheA (a histidine kinase) $\rightarrow$ CheY (a phospho-activated response regulator)] (for review, see Stock et al. 1992), more rigorous biochemical experiments now show that CheW's function is solely as a "coupling protein" between the CheA kinase and the receptors, stimulating CheA activity more than 10-fold (Borkovich and Simon 1990; McNally and Matsumara 1991; Ninfa et al. 1991; Gegner et al. 1992). A second example comes from mammalian signal transduction. Recent reports reveal that the proteins Raf-1 kinase and its regulator Ras:GTP interact to form a complex (Voitek et al. 1993; Warne et al. 1993; Zhang et al. 1993), and that MAP kinase kinase can be found in this complex (Moodie et al. 1993; Van Aelst et al. 1993).

Further investigation will determine how Ste5's interaction with Fus3 and other protein kinases contributes to signal transduction. The association of multiple protein kinases into a ternary complex with Ste5 might enable the proper set of protein kinases to interact, assuring specificity. Such specificity might be important in light of the existence of at least three MAP kinase cascades in S. cerevisiae (Errede and Levin 1993). The conservation of MAP kinase signal transduction modules across widely divergent organisms raises the question of whether Ste5 is also conserved in other MAP kinase signal transduction cascades. It is tempting to speculate that the Ste5-dependent associations we detect in yeast provide a paradigm for an analogous form of regulation in higher eukaryotes.

\section{Materials and methods}

Media, strains, and yeast strain construction

Yeast media, containing either $2 \%$ dextrose, $2 \%$ raffinose or $2 \%$ galactose, were prepared as described (Sherman et al. 1986). All strains (Table 2) except the EGY048 derivatives are isogenic sst1 1 derivatives of W303 (EY699, Elion et al. 1991b). SST1 encodes a protease that degrades $\alpha$-factor /Ciejek and Thorner 1979). The fus 3 point mutants are described elsewhere (B. Satterberg and E.A. Elion, in prep.). Yeast transformations were performed by the lithium acetate procedure (Ito et al. 1983). Gene replacement (Rothstein 1983) was used to construct ste derivatives using pJB220, pJB221, pNC149, pNC202, and pNC163.

\section{Plasmids and plasmid construction}

Plasmids are listed in Table 3. Standard methods were used for bacterial transformations, plasmid DNA preparation, and plas- mid constructions (Sambrook et al. 1989) using restriction and DNA-modifying enzymes from New England Biolabs. pYBS351 was made by cloning the 2-kb EcoRI fus3R42-HA fragment from pYEE127 (Elion et al. 1993) into pYEE1102. pYBS186 was made by first subcloning the 3-kb KpnI STE5 fragment of pJB215 (gift of J. Brill, MIT) into the KpnI site of pUC118, to make pYBS97; then subcloning the 3-kb BamHI STE5 fragment (containing all but the first 23 amino acids of the STE5 gene) from pYBS97 into pEMBL-GST to make pYBS186. Note that this GST-Ste5 construct complements the mating defect of a ste $5 \Delta$ strain when it is expressed under either repressive (i.e., glucose) or inducing (i.e. galactose) conditions. pYBS138 is YCplac33/Gietz and Sugino 1988) with STE5 on a 4-kb BamHI-XbaI fragment. pYBS 146 contains the $3-\mathrm{kb}$ BamHI STE5 fragment from pYBS97 in-frame after a tripartite fusion protein that contains, in order, an ATG start codon, the SV40 nuclear localization signal, the transcriptional acidic-activation domain B42, and HA, in pIG4-5 (Zervos et al. 1993). pYBS150 (Elion et al. 1993) contains a $1-\mathrm{kb}$ BamHI-BglII fragment containing the CDC28 open reading frame (derived from pGALCDC28, gift of J. Celenza), into the BamHI site of pYBS139 (a derivative of pYBS135 in which the EcoRI site was filled-in to create the proper reading framel.

\section{$\alpha$-Factor sensitivity, and $\beta$-galactosidase assays}

$\alpha$-factor sensitivity was measured by a halo assay as described (Elion et al. 1993), using $50 \mu \mathrm{l}$ of an overnight culture of yeast cells and $5 \mu \mathrm{l}$ of $0.1 \mathrm{~mm}$ synthetic $\alpha$-factor in dimethylsulfoxide (synthesized by C. Dahl, Harvard Medical School). All halos were done in duplicate. $\beta$-Galactosidase activity was measured as described (Craven et al. 1965), using yeast extracts prepared by glass bead breakage, as described below.

\section{Preparation of yeast extracts}

Yeast strains containing plasmids were grown at $30^{\circ} \mathrm{C}$ in selective (SC) media with $2 \%$ dextrose to an $A_{600}$ of $0.4-0.8$ and then induced for $1 \mathrm{hr}$ at $30^{\circ} \mathrm{C}$ with $50 \mathrm{~nm} \alpha$-factor. Genes under control of the GAL1 promoter were induced by first growing strains overnight in selective media with $2 \%$ raffinose to an $A_{600}$ between 0.5 and 1.2 , followed by growth for $5-6 \mathrm{hr}$ in $2-3$ volumes of selective media containing $2 \%$ galactose, and then, where indicated, induced with $\alpha$-factor. Cells were collected at $4^{\circ} \mathrm{C}$, washed once with cold sterile water, then either frozen in dry ice/ethanol or used immediately for protein extract preparation. Whole cell extracts were prepared by lysis with glass beads, as described in (Elion et al. 1993), including $250 \mathrm{mM} \mathrm{NaCl}$ in the lysis buffer. Protein concentrations were determined with the Bio-Rad protein assay.

\section{Preparation of immune complexes for kinase assays and for} coimmunoprecipitation experiments

All immune complexes and kinase assays were performed exactly as described (Elion et al. 1993), except for the B42 fusion proteins, which were immunoprecipitated in RIPA buffer (Sambrook et al. 1989). BSA (1\%) was included in coimmunoprecipitation experiments. Casein and MBP were added as substrates in the kinase assays at a final concentration of $0.5 \mathrm{mg} / \mathrm{ml}$.

\section{Western blotting}

Samples were electrophoresed by SDS-PAGE on $7.5 \%, 8 \%$ or $10 \%$ polyacrylamide gels /with acrylamide/bis-acrylamide ratios of either $38: 2$ or $30: 0.8$, as noted in each figure legend. 
Table 2. Yeast strains

\begin{tabular}{|c|c|c|}
\hline Strain & Genotype & Source \\
\hline \multicolumn{3}{|c|}{ All strains are W303 background, except EGY048 } \\
\hline EY957 & MATa ade2-1 his3-11,15 leu2-3,112 sst1s trp1-1 ura3-1 can1-100 $\mathrm{Gal}^{+}$ & Elion et al. (1993) \\
\hline EY940 & EY957 fus3-6::LEU2 & Elion et al. (1993) \\
\hline EY959 & $E Y 940+p Y E E 114$ & Elion et al. (1993) \\
\hline EY960 & $E Y 940+p Y E E 121$ & Elion et al. (1993) \\
\hline EY1144 & $E Y 940+p Y E E 128$ & Elion et al. (1993) \\
\hline EY966 & EY940 kss1::HIS3 & Elion et al. $\{1993\}$ \\
\hline BY360 & EY966 fus3::LEU2 replaced with fus3-205 & B. Satterberg and E. Elion (in prep.) \\
\hline BY366 & EY966 fus3::LEU2 replaced with fus3-211 & B. Satterberg and E. Elion (in prep.) \\
\hline BY367 & EY966 fus3::LEU2 replaced with fus3-212 & B. Satterberg and E. Elion (in prep.) \\
\hline BY369 & EY966 fus3::LEU2 replaced with fus3-2 & B. Satterberg and E. Elion (in prep.) \\
\hline EY1466 & BY360 + pJB207 + YEP24 & this study \\
\hline EY 1467 & $\mathrm{BY} 366+\mathrm{pJB} 207+\mathrm{p} / \mathrm{B} 223$ & this study \\
\hline EY1469 & BY369 + pIB207 + YEp24 & this study \\
\hline EY1470 & BY366 + pJB207 + YEp24 & this study \\
\hline EY1471 & $\mathrm{BY} 360+\mathrm{pJB} 207+\mathrm{pJB} 223$ & this study \\
\hline EY1472 & $\mathrm{BY} 369+\mathrm{pJB} 207+\mathrm{pJB223}$ & this study \\
\hline EGY048 & MATa LEU2::pLexAop6-LEU2 ura3 his3 trp1 Gal ${ }^{+}$ & Zervos et al. (1993) \\
\hline BY872 & $E G Y 048+p / K 103+$ LexA202PL + pIG4-5 & this study \\
\hline BY874 & $E G Y 048+p I K 103+L e x A 202 P L+p Y B S 150$ & this study \\
\hline BY873 & $E G Y 048+p / K 103+$ LexA202PL + pYBS146 & this study \\
\hline BY875 & $E G Y 048+p / K 103+p H M \varnothing+p / G 4-5$ & this study \\
\hline BY876 & $E G Y 048+p / K 103+p H M \varnothing+p Y B S 150$ & this study \\
\hline BY818 & $E G Y 048+p / K 103+p H M \varnothing+p Y B S 146$ & this study \\
\hline BY716 & $E G Y 048+p / K 103+$ LexA-FUS3 + p/G4-5 & this study \\
\hline BY719 & EGY048 + p/K103 + LexA-FUS3 $+p Y B S 150$ & this study \\
\hline BY718 & EGY048 + p/K103 + LexA.FUS3 + pYBS146 & this study \\
\hline EY1095 & EY957 fus3-8::ADE2 & this study \\
\hline BY783 & $E Y 1095+p Y E E 1100+p E M B L-G S T$ & this study \\
\hline BY784 & $E Y 1095+p Y E E 1102+p E M B L-G S T$ & this study \\
\hline BY785 & $E Y 1095+p Y E E 1100+p Y B S 186$ & this study \\
\hline BY786 & $E Y 1095+p Y E E 1102+p Y B S 186$ & this study \\
\hline JY165 & $E Y 1095+p Y B S 351+p Y B S 186$ & this study \\
\hline EY1450 & $E Y 1095+Y C p 403+p Y B S 186$ & this study \\
\hline EY1452 & $E Y 1095+p Y E E 1102+p Y B S 186$ & this study \\
\hline BY819 & EY1026 with ste5::TRP1 replaced for ste5::URA3 & this study \\
\hline BY843 & $B Y 819+p Y E E 1100+p E M B L-G S T$ & this study \\
\hline BY844 & $B Y 819+p Y E E 1102+p E M B L-G S T$ & this study \\
\hline BY845 & $B Y 819+p Y E E 1100+p Y B S 186$ & this study \\
\hline BY846 & $B Y 819+p Y E E 1102+p Y B S 186$ & this study \\
\hline BY847 & $B Y 819+p Y E E 1100+p Y B S 138$ & this study \\
\hline BY848 & $B Y 819+p Y E E 1102+p Y B S 138$ & this study \\
\hline JY161 & $B Y 819+p Y B S 351+p Y B S 186$ & this study \\
\hline JY106 & $E Y 940+p / B 223+p Y E E 1100$ & this study \\
\hline JY108 & $E Y 940+p / B 223+p Y E E 1102$ & this study \\
\hline IY177 & $E Y 940+Y E p 24+p Y E E 1100$ & this study \\
\hline JY147 & $E Y 940+Y E p 24+p Y E E 1102$ & this study \\
\hline JY173 & $E Y 940+Y E p 24+p Y B S 351$ & this study \\
\hline EY1026 & EY940 ste $5:: U R A 3$ & this study \\
\hline JY179 & $E Y 1026+p Y E E 1100$ & this study \\
\hline JY181 & $E Y 1026+p Y E E 1102$ & this study \\
\hline JY183 & $E Y 1026+p Y B S 351$ & this study \\
\hline
\end{tabular}


Table 3. Plasmids

\begin{tabular}{|c|c|c|}
\hline Plasmid & Markers & Source \\
\hline pYEE114 & URA3 CEN FUS3 & Elion et al. (1993) \\
\hline pYEE121 & URA3 CEN FUS3-HA & Elion et al. (1993) \\
\hline pYEE 128 & URA3 CEN fus $3 R 42-H A$ & Elion et al. (1993) \\
\hline YCp403 & HIS3 CEN & Stearns et al. (1990) \\
\hline pYEE1100 & HIS3 CEN FUS3 & Elion et al. (1993) \\
\hline pYEE1102 & HIS3 CEN FUS3-HA & Elion et al. (1993) \\
\hline pYBS351 & HIS3 CEN fus3R42-HA & this study \\
\hline YEp24 & $U R A 32 \mu$ & \\
\hline pYBS101 & URA3 $2 \mu$ STE12 & B. Satterberg and E. Elion (in prep.) \\
\hline pYBS102 & $U R A 32 \mu F A R 1$ & Elion et al. (1993) \\
\hline pJB223 & URA3 $2 \mu$ STE5 & J. Brill (MIT) \\
\hline pYBS138 & URA3 CEN STE5 & this study \\
\hline pSL1655 & URA3 STE11-4 & Stevenson et al. (1992) \\
\hline pJB220 & ste5 101::TRP1 & J. Brill \\
\hline pIB221 & ste5 $102:: U R A 3$ & J. Brill \\
\hline pNC149 & ste7-3::URA3 & Company et al. (1988) \\
\hline pNC202 & ste11-4::URA3 & B. Errede (University of NC, Chapel Hill) \\
\hline $\mathrm{pNC} 163$ & ste 12-1::URA3 & Company et al. (1988) \\
\hline pJB207 & FUS1-lacZ LEU2 $2 \mu$ & J. Brill \\
\hline LexA202PL & HIS3 $2 \mu p A D H 1-L e x A$ & Zervos et al. (1993) \\
\hline LexAFUS3 & HIS3 $2 \mu$ pADH1-LexA-FUS3 & Zervos et al. (1993) \\
\hline $\mathrm{pHM} \varnothing$ & HIS3 $2 \mu p A D H 1-L e x A-B i c o i d$ & Zervos et al. (1993) \\
\hline pJG4-5 & $T R P 12 \mu p G A L 1-B 42-H A$ & Zervos et al. (1993) \\
\hline pYBS146 & TRP1 $2 \mu p G A L 1-B 42-H A-S T E 5$ & this study \\
\hline pYBS 150 & TRP1 $2 \mu p G A L 1-B 42-H A-C D C 28$ & Elion et al. (1993) \\
\hline pJK103 & URA3 $2 \mu$ pLexA-IacZ & Kamens et al. (1990) \\
\hline pEMBL-GST & $U R A 32 \mu p G A L-G S T$ & C. Chan (University of Texas, Austin) \\
\hline pYBS186 & $U R A 32 \mu p G A L-G S T-S T E 5$ & this study \\
\hline
\end{tabular}

Western blotting was performed essentially as described (Burnette 1981), with the modifications noted in (Elion et al. 1993). Nitrocellulose filters were blocked in $20 \mathrm{~mm}$ Tris at $\mathrm{pH} 7.5,150$ $\mathrm{mm} \mathrm{NaCl}, 0.05 \%$ Tween-20 (TBST) containing $5 \%$ nonfat-dry milk, then incubated with primary antibody diluted in TBST$5 \%$ milk overnight at $4^{\circ} \mathrm{C}$ or $2 \mathrm{hr}$ at room temperature. Anti-HA mouse monoclonal antibody $12 \mathrm{CA} 5$ tissue culture supernatant was provided by Harvard University antibody facility; anti-GST affinity-purified rabbit antiserum was a gift of $R$. Van Etten, Harvard Medical School. Immunoblots were washed five times with TBST at room temperature, and then incubated for $1-2 \mathrm{hr}$ at room temperature with secondary antibody (HRP-conjugated goat-anti-mouse IgG or HRP-conjugated goat-anti-rabbit IgG, purchased from Bio-Rad) in TBST-5\% milk. After five washes in TBST and two washes in TBS, the blots were developed with the Amersham ECL kit, according to manufacturer's instructions using Fuji RX X-ray film.

Precipitation, purification, and thrombin-cleavage, of GST proteins

GST-Ste5 was purified with glutathione-agarose (Sigma) following the same approach used for immunoprecipitations (Elion et al. 1993), using $200 \mu \mathrm{g}$ of whole cell extract in the presence of modified $\mathrm{H}$ buffer, $150 \mathrm{mM} \mathrm{NaCl}$, and $1 \% \mathrm{BSA}$.
Non-specific aggregates were first pelleted by a $15 \mathrm{~min} \mathrm{mi}-$ crofuge spin at $4^{\circ} \mathrm{C}$. The supernatant was then incubated with $25 \mu \mathrm{l}$ of glutathione agarose (at $75 \mu \mathrm{g} / \mu \mathrm{l}$ ) at $4^{\circ} \mathrm{C}$ for $30-60 \mathrm{~min}$ with constant rotation. Glutathione precipitates were pelleted by a 15-sec spin at $1500 \mathrm{rpm}$ in a Sorvall RT6000B centrifuge, washed two times with modified $\mathrm{H}$ buffer with $150 \mathrm{~mm} \mathrm{NaCl}$, and then three times with modified $\mathrm{H}$ buffer. Samples to be analyzed by gel electrophoresis were resuspended in $30 \mu \mathrm{I} 2 \times$ SDS-PAGE sample buffer (Sambrook et al. 1989) and boiled for $5 \mathrm{~min}$. Samples to be cleaved with thrombin were washed once in PBS with $1 \% \mathrm{TX}-100$, once in $50 \mathrm{~mm}$ Tris at $\mathrm{pH} 7.5$ with 150 $\mathrm{mM} \mathrm{NaCl}$, and once in TCB (thrombin cleavage buffer: $2.5 \mathrm{mM}$ $\mathrm{CaCl}_{2}, 50 \mathrm{~mm}$ Tris at $\mathrm{pH} 7.5,150 \mathrm{~mm} \mathrm{NaCl}$ ), as described (Ausubel et al. 1992), except that all buffers were cold. The samples were then resuspended in a final volume of $\sim 20 \mu \mathrm{TCB}$, to which was added either $5 \mu$ l of thrombin $/ 0.1$ unit $/ \mu l$ in $\mathrm{TCB}$; Sigma T-6759; stored at $\left.-20^{\circ} \mathrm{C}\right)$ and $2 \mu \mathrm{l}$ of heparin $(10$ units $/ \mu \mathrm{l}$ in TCB; Sigma H-3393; stored at $-20^{\circ} \mathrm{Cl}$, or $7 \mu \mathrm{l}$ of TCB. Reactions were carried out for $10 \mathrm{~min}$ at $30^{\circ} \mathrm{C}$. These cleavage conditions were determined empirically, based on previously described conditions (Chang 1985). Reactions were stopped by addition of $30 \mu \mathrm{l}$ of $2 \times$ SDS-PAGE sample buffer followed by boiling for $5 \mathrm{~min}$.

Phosphorylated GST-Ste5 was purified from Fus3-HA immune complexes as follows: First, $1 \mathrm{ml}$ of RIPA buffer (either at 
room temperature or $42^{\circ} \mathrm{C}$ ) was added to Fus3-HA immunoprecipitates after an $8 \mathrm{~min}$ kinase reaction, and the sample was mixed by inverting $\sim 10$ times over a $5-10 \mathrm{~min}$ period at $23^{\circ} \mathrm{C}$. The protein-A-Sepharose and associated proteins were then pelleted, and the supernatant was transferred to a tube containing $25 \mu l$ glutathione-agarose. The glutathione precipitation was then done at $4^{\circ} \mathrm{C}$ in RIPA buffer, and the subsequent thrombin cleavage was performed exactly as described above.

\section{Preparation of GST-Ste5 for kinase assays}

GST-Ste5 was purified from $200 \mu \mathrm{g}$ of whole cell extract using glutathione agarose exactly as described above. Glutathione precipitates were washed once with modified $\mathrm{H}$ buffer containing $150 \mathrm{mM} \mathrm{NaCl}$, twice with modified $\mathrm{H}$ buffer and twice with kinase buffer. Kinase reactions were then performed exactly as described (Elion et al. 1993).

\section{Acknowledgments}

We especially thank J.A. Brill and G.R. Fink for STE5 plasmids. We also thank B. Stevenson and G.F. Sprague, Jr. for the STE11-4 plasmid, B. Errede for the ste disruption plasmids, C. Chan for the pEMBL-GST plasmid, and R. Van Etten for the antiserum to GST. We thank Fred Winston and Joan Ruderman for helpful comments on the manuscript. D. Lyons provided superb technical assistance. This work was supported by the National Institutes of Health grant (RO1-GM46962-01) and a new investigator grant from the General Cinema Corporation Charitable Foundation.

The publication costs of this article were defrayed in part by payment of page charges. This article must therefore be hereby marked "advertisement" in accordance with 18 USC section 1734 solely to indicate this fact.

\section{References}

Ausubel, F.M., R. Brent, R.E. Kingston, D.D. Moore, J.G. Seidman, J.A. Smith, and K. Struhl. 1992. Current protocols in molecular biology. John Wiley \& Sons, New York.

Blinder, D., S. Bouvier, and D. Jenness. 1989. Constitutive mutants in the yeast pheromone response: Ordered function of the gene products. Cell 56: 479-486.

Borkovich, K.A. and M.I. Simon. 1990. The dynamics of protein phosphorylation in bacterial chemotaxis. Cell 63: 13391348.

Boulton, T.G., S.H. Nye, D.J. Robbins, N.Y. Ip, E. Radziejewska, S.D. Morgenbesser, R.A. DePinho, N. Panayotatos, M.H. Cobb, and G.D. Yancopoulos. 1991. ERKs: A family of protein-serine/threonine kinases that are activated and tyrosine phosphorylated in response to insulin and NGF. Cell 65: 663-675.

Burnette, W.N. 1981. Western blotting: Electrophoretic transfer of proteins from sodium dodecyl sulfate polyacrylamide gels to unmodified nitrocellulose and radiographic detection with antibody and radio-iodinated Protein A. Anal. Biochem. 112: 195-203.

Cairns, B.R., S.W. Ramer, and R.D. Kornberg. 1992. Order of action of components in the yeast pheromone response pathway revealed with a dominant allele of the STE 11 kinase and the multiple phosphorylation of the STE7 kinase. Genes \& Dev. 6: 1305-1318.

Chang, J.-Y. 1985. Thrombin specificity: Requirement for apolar amino acids adjacent to the thrombin cleavage site of polypeptide substrate. Eur. I. Biochem. 151:217-224.

Ciejek, E. and J. Thorner. 1979. Recovery of S. cerevisiae a cells from Gl arrest by $\alpha$ factor requires endopeptidase action. Cell 18: 623-635.

Cobb, M.H., T.G. Boulton, and D.J. Robbins. 1991. Extracellular signal-regulated kinases: ERKs in progress. Cell Reg. 2: 965978.

Courchesne, W.E., R. Kunisawa, and J. Thorner. 1989. A putative protein kinase overcomes pheromone-induced arrest of cell cycling in S. cerevisiae. Cell 58: 1107-1119.

Craven, G.R., E.J. Steers, J.L. Bethune, and C.B. Anfinsen. 1965. Purification, composition, and molecular weight of the $\beta$-galactosidase of Escherichia coli K12. I. Biol. Chem. 240: 2468-2477.

Crews, C.M. and R.L. Erikson. 1992. Purification of a murine protein-tyrosine/threonine kinase that phosphorylates and activates the Erk-1 gene product: Relationship to the fission yeast byr1 gene product. Proc. Natl. Acad. Sci. 89: 82058209.

Dolan, J.W. and S. Fields. 1990. Overproduction of the yeast STE12 protein leads to constitutive transcriptional induction. Genes \& Dev. 4: 492-502.

Dolan, J.W., C. Kirkman, and S. Fields. 1989. The yeast STE12 protein binds to the DNA sequence mediating pheromone induction. Proc. Natl. Acad. Sci. 86: 5703-5707.

Elion, E.A., P.L. Grisafi, and G.R. Fink 1990. FUS3 encodes a $\mathrm{cdc} 2 / \mathrm{CDC} 28$-related kinase required for the transition from mitosis into conjugation. Cell 60: 649-664.

Elion, E.A., J.A. Brill, and G.R. Fink. 1991a. Functional redundancy in the yeast cell cycle: FUS3 and KSS1 have both overlapping and unique functions. Cold Spring Harbor Symp. Quant. Biol. 56: 41-49.

- 1991 b. FUS3 represses CLN1 and CLN2 and in concert with KSSl promotes signal transduction. Proc. Natl. Acad. Sci. 88: 9392-9396.

Elion, E.A., B. Satterberg, and J.E. Kranz. 1993. FUS3 phosphorylates multiple components of the mating signal transduction cascade: Evidence for STE12 and FAR1. Mol. Biol. Cell 4: 495-510.

Errede, B. and D.E. Levin. 1993. A conserved kinase cascade for MAP kinase activation in yeast. Curr. Op. Cell Biol. 5: 254 260.

Errede, B., A. Gartner, Z. Zhou, K. Nasmyth, and G. Ammerer. 1993. MAP kinase-related FUS3 from $S$. cerevisiae is activated by STE7 in vitro. Nature 362: 261-264.

Fields, S. and O. Song. 1989. A novel genetic system to detect protein-protein interactions. Nature 340: 245-246.

Gartner, A., K. Nasmyth, and G. Ammerer. 1992. Signal transduction in Saccharomyces cerevisiae requires tyrosine and threonine phosphorylation of FUS3 and KSS1. Genes \& Dev. 6: $1280-1292$.

Gegner, I.A., D.R. Graham, A.F. Roth, and F.W. Dahlquist. 1992. Assembly of an MCP receptor, CheW, and kinase CheA complex in the bacterial chemotaxis signal transduction pathway. Cell 70: 975-982.

Gietz, R.D. and A. Sugino. 1988. New yeast-Escherichia coli shuttle vectors constructed with in vitro mutagenized yeast genes lacking six-base pair restriction sites. Gene 74: 527534.

Hartwell, L.H. 1980. Mutants of Saccharomyces cerevisiae unresponsive to cell division control by polypeptide mating pheromone. J. Cell Biol. 85: 811-822. 
Hasson, M.S., D. Blinder, J. Thorner, and D.D. Jenness. 1994. Mutational activation of the STE5 gene product bypasses the requirement for $G$ protein $\beta$ and $\gamma$ subunits in the yeast pheromone response pathway. Mol. Cell Biol. 14: (in press).

Ito, H., Y. Fukada, K. Murata, and A. Kimura. 1983. Transformation of intact yeast cells with alkali cations. I. Bacteriol. 153: $163-168$

Jarvik, J. and D. Botstein. 1975. Conditional lethal mutations that suppress genetic defects in morphogenesis by altering structural proteins. Proc. Natl. Acad. Sci. 72: 2738-2742.

Kamens, J., P. Richardson, G. Mosialos, R. Brent, and T. Gilmore. 1990. Oncogenic transformation by vRel requires an amino-terminal activation domain. Mol. Cell. Biol. 10: 2840-2847.

Kosako, H., E. Nishida, and Y. Gotoh. 1993. cDNA cloning of MAP kinase kinase reveals kinase cascade pathways in yeasts to vertebrates. EMBO /. 12: 787-794.

Kurjan, J. 1992. Pheromone response in yeast. Annu. Rev. Biochem. 61: 1097-1129.

Lange-Carter, C.A., C.M. Pleiman, A.M. Gardner, K.J. Blumer, and G.L. Johnson. 1993. A divergence in the MAP kinase regulatory network defined by MEK kinase and Raf. Science 260: 315-319.

Leberer, E., D. Dignard, D. Harcus, D.Y. Thomas, and M. Whiteway. 1992. The protein kinase homologue Ste20p is required to link the yeast pheromone response G-protein $\beta \gamma$ subunits to downstream signaling components. EMBO /. 11:48154824.

Leberer, E., D. Dignard, D. Harcus, L. Hougan, M. Whiteway, and D.Y. Thomas. 1993. Cloning of the Saccharomyces cerevisiae STE5 as a suppressor of a Ste20 protein kinase mutant: Structural and functional similarity of Ste5 to Farl. Mol. Gen. Genet. 241: 241-254.

Lee, R.-M., M.H. Cobb, and P.J. Blackshear. 1992. Evidence that extracellular signal-regulated kinases are the insulin-activated Raf-I kinase kinases. J. Biol. Chem. 267: 1088-1092.

Ma, J. and M. Ptashne. 1987. A new class of transcriptional activators. Cell 51: 113-119.

MacKay, V.L. 1983. Cloning of yeast STE genes in 2-micron vectors. Methods Enzymol. 101: 325-343.

MacKay, V.L. and T.R. Manney. 1974. Mutations affecting sexual conjugation and related processes in Saccharomyces cerevisiae. II. Genetic analysis of nonmating mutants. Genetics 76: 273-288.

McNally, D.F. and P. Matsumara. 1991. Bacterial chemotaxis signaling complexes: Formation of a CheA/CheW complex enhances autophosphorylation and affinity for CheY. Proc. Natl. Acad. Sci. 88: 6269-6273.

Moodie, S.A., B.M. Willumsen, M.J. Weber, and A. Wolfman. 1993. Complexes of Ras-GTP with Raf-1 and mitogen-activated protein kinase kinase. Science 260: 1658-1661.

Mukai, Y., S. Harashima, and Y. Oshima. 1993. Function of the Ste signal transduction pathway for mating pheromones sustains MAT $\alpha$ l transcription in Saccharomyces cerevisiae. Mol. Cell. Biol. 13: 2050-2060.

Neiman, A.M., B.J. Stevenson, H.-P. Xu, G.F. Sprague, I. Herskowitz, M. Wigler, and S. Marcus. 1993. Functional homology of protein kinases required for sexual differentiation in Schizosaccharomyces pombe and Saccharomyces cerevisiae suggests a conserved signal transduction module in eukary. otic organisms. Mol. Biol. Cell 4: 107-120.

Ninfa, E.G., A. Stock, S. Mowbray, and J. Stock. 1991. Reconstitution of the bacterial chemotaxis signal transduction system from purified components. I. Biol. Chem. 266: 9764 9770.

Pelech, S.L. and J.S. Sanghera. 1992a. MAP kinases: Charting the regulatory pathways. Science 257: 1355-1356.

1992b. Mitogen-activated protein kinases: Versatile transducers for cell signalling. Trends Biochem. Sci. 17: 233-238.

Perlman, R., D. Yablonski, G. Simchen, and A. Levitzki. 1993. Cloning of the STE5 gene of Saccharomyces cerevisiae as a suppressor of the mating defect of $c d c 25$ temperature-sensitive mutants. Proc. Natl. Acad. Sci. 90: 5474-5478.

Peter, M., A. Gartner, J. Horecka, G. Ammerer, and I. Herskowitz. 1993. FAR1 links the signal transduction pathway to the cell cycle machinery in yeast. Cell 73: 747-760.

Posada, J. and J.A. Cooper. 1992. Molecular signal interplay between serine, threonine, and tyrosine phosphorylation. $\mathrm{Mol}$. Biol. Cell 3: 583-592.

Ramer, S.A. and R.W. Davis. 1993. A dominant truncation allele identifies a gene, STE20, that encodes a putative protein $\mathrm{ki}$ nase necessary for mating in Saccharomyces cerevisiae. Proc. Natl. Acad. Sci. 90: 452-456.

Ray, L.B. and T.W. Sturgill. 1987. Rapid stimulation by insulin of a serine/threonine kinase in 3'T3-Ll adipocytes that phosphorylates microtubule-associated protein 2 in vitro. Proc. Natl. Acad. Sci. 84: 1502-1506.

Robbins, D.J., E. Zhen, H. Owaki, C.A. Vanderbilt, D. Ebert, T.D. Geppert, and M.H. Cobb. 1993. Regulation and properties of extracellular signal-regulated protein kinases 1 and 2 in vitro. J. Biol. Chem. 268: 5097-5106.

Rothstein, J. 1983. One-step gene disruption in yeast. Methods Enzymol. 101: 202-211.

Sambrook, I., E.F. Fritsch, and T. Maniatis. 1989. Molecular cloning: A laboratory manual. Cold Spring Harbor Laboratory Press, Cold Spring Harbor, New York.

Seger, R., D. Seger, F.J. Lozeman, N.G. Ahn, L.M. Graves, J.S. Campbell, L. Ericsson, M. Harrylock, A.M. Jensen, and E.G. Krebs. 1992. Human T-cell mitogen-activated protein kinase kinases are related to yeast signal transduction kinases. $J$. Biol. Chem. 267: 25628-25631.

Sherman, F., G.R. Fink, and J.B. Hicks. 1986. Methods in yeast genetics. Cold Spring Harbor Laboratory, Cold Spring Harbor, New York.

Sprague, G.F. Jr. and J.W. Thorner. 1994. Pheromone response and signal transduction during the mating process of Saccharomyces cerevisiae. In The molecular and cellular biology of the yeast saccharomyces. Cold Spring Harbor Laboratory Press, Cold Spring Harbor, New York. (In press.)

Stearns, T., H. Ma, and D. Botstein. 1990. Manipulating the yeast genome using plasmid vectors. Methods Enzymol. 185: 280-297.

Stevenson, B.J., N. Rhodes, B. Errede, and G.F. Sprague Jr. 1992. Constitutive mutants of the protein kinase STEll activate the yeast pheromone response pathway in the absence of the G protein. Genes \& Dev. 6: 1293-1304.

Stock, J.B., M.G. Surette, W.R. McCleary, and A.M. Stock. 1992. Signal transduction in bacterial chemotaxis. /. Biol. Chem. 267: 19753-19756.

Van Aelst, L., M. Barr, S. Marcus, A. Polverino, and M. Wigler. 1993. Complex formation between RAS and RAF and other protein kinases. Proc. Natl. Acad. Sci. 90: 6213-6217.

Vojtek, A.B., S.M. Hollenberg, and J.A. Cooper. 1993. Mammalian Ras interferes directly with the serine/threonine kinase Raf. Cell 74: 205-214.

Warne, P.H., P.R. Viciana, and J. Downward. 1993. Direct interaction of Ras and the amino-terminal region of Raf- 1 in vitro. Nature 364: 352-355.

Whiteway, M., L. Hougan, and D.Y. Thomas. 1990. Overexpression of the STE4 gene leads to mating response in haploid Saccharomyces cerevisiae. Mol. Cell. Biol. 10: 217-222. 
Zervos, A.S., J. Gyuris, and R. Brent. 1993. Mxil, a protein that specifically interacts with Max to bind Myc-Max recognition sites. Cell 72: 223-232.

Zhang, X., J. Settleman, J.M. Kyriakis, E. Takeuchi-Suzuki, S.J. Eledge, M.S. Marshall, J.T. Bruder, U.R. Rapp, and J. Avruch. 1993. Normal and oncogenic p2lras proteins bind to the amino-terminal regulatory domain of c-Raf-1. Nature 364: 308-313.

Zhou, Z., A. Gartner, R. Cade, G. Ammerer, and B. Errede. 1993. Pheromone-induced signal transduction in Saccharomyces cerevisiae requires the sequential function of three protein kinases. Mol. Cell. Biol. 13: 2069-2080. 


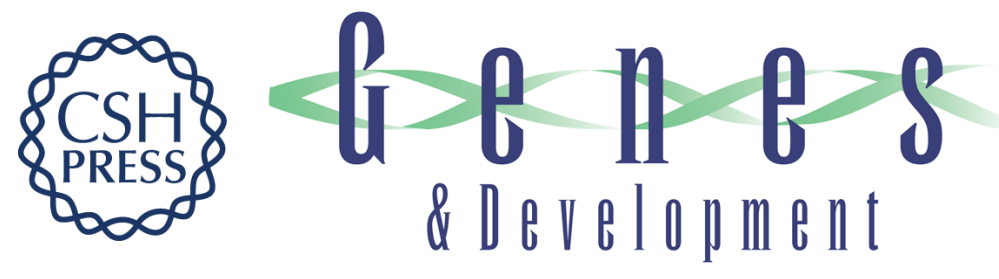

\section{The MAP kinase Fus3 associates with and phosphorylates the upstream signaling component Ste5.}

J E Kranz, B Satterberg and E A Elion

Genes Dev. 1994, 8:

Access the most recent version at doi:10.1101/gad.8.3.313

References This article cites 61 articles, 33 of which can be accessed free at:

http://genesdev.cshlp.org/content/8/3/313.full.html\#ref-list-1

License

Email Alerting Receive free email alerts when new articles cite this article - sign up in the box at the top Service right corner of the article or click here.

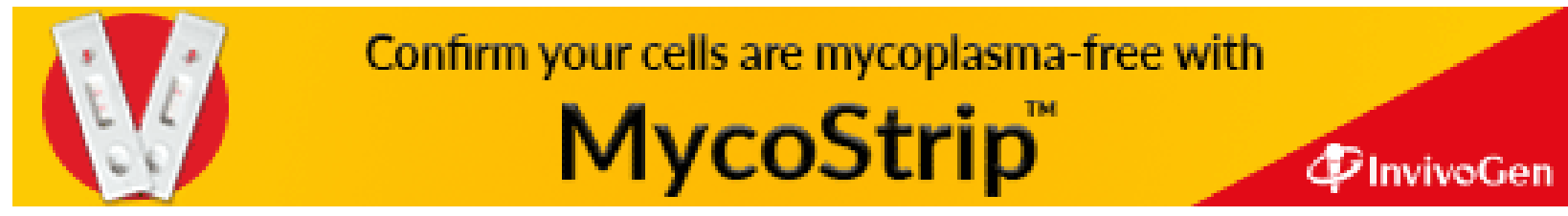

